\title{
SISTEM PENUNJANG KEPUTUSAN UNTUK PENGEMBANGAN INDUSTRI PENGOLAHAN PRODUK TURUNAN KELAPA SAWIT
}

\author{
Hermiza Mardesci, S.TP., MP \\ Dosen Teknologi Pangan Faperta UNISI \\ mimzaaci@yahoo.co.id
}

\begin{abstract}
Abstrak
Indonesia merupakan Negara penghasil CPO terbesar di dunia. Namun industri pengolahan produk turunannya belum berkembang dengan baik. Untuk itu pada tulisan ini akan membahas kajian tentang pengembangan industri pengolahan produk turunan dari CPO. Kajian tersebut meliputi pemilihan alternatif produk turunan CPO yang potensial untuk dikembangkan, dilihat dari aspek potensi pasar, kondisi bahan baku, teknologi proses, nilai tambah produk, dan daya serap tenaga kerja. Dari hasil analisis dengan metode Analytical Hierarchy Process (AHP) dengan aplikasi Expert Choice diperoleh oleokimia sebagai alternatif terbaik untuk dikembangkan.
\end{abstract}

\section{PENDAHULUAN}

\section{Latar Belakang}

Tanaman Kelapa Sawit (Elais Guinensis Jack) memiliki arti penting bagi pembangunan perkebunan nasional Indonesia. Selain mampu menciptakan kesempatan kerja yang mengarah pada kesejahteraan masyarakat, juga sebagai sumber perolehan devisa Negara.

Industri pengolahan $\mathrm{CPO}$ telah berkembang dengan pesat. Saat ini jumlah unit pengolahan di seluruh Indonesia mencapai 320 unit dengan kapasitas olah 13.520 ton TBS per jam. Namun industri pengolahan produk turunannya, kecuali minyak goreng masih belum berkembang. Industri oleokimia Indonesia sampai tahun 2000 baru memproduksi oleokimia $10,8 \%$ dari produksi dunia.

Sejalan dengan peningkatan ekspor $\mathrm{CPO}$, juga terjadi peningkatan ekspor minyak inti sawit dan oil palm cake yang mencapai nilai 338 juta US \$ pada tahun 1997. Belum kuatnya industri hilir dan rendahnya kapasitas dari industri pengolahan, berimplikasi pada ekspor sawit Indonesia hanya dalam bentuk CPO yang nilainya terendah.

Penggunaan terbesar minyak sawit adalah bahan dasar pembuatan minyak goreng (sekitar 71\%), sedangkan bila digabung dengan margarin/shortening sekitar $75 \%$. Sisanya sekitar 25\% dikonsumsi dalam bentuk sabun, oleokimia dan bentuk-bentuk lainnya. Komoditas minyak sawit memiliki berbagai kegunaan baik untuk industri pangan maupun non pangan. Prospek dan fluktuasi pengembangan minyak sawit tidak hanya mengikuti kecendrungan permintaan lokal dan dunia untuk minyak nabati, tetapi juga berhubungan dengan pengembangan sumber minyak nabati lainnya, seperti kedelai, biji bunga matahari, rapeseed oil, olive oil, dan sebagainya (Saragih, 1998). 


\section{Permasalahan}

Oleh karena belum berkembangnya produk turunan CPO di Indonesia, maka perlu dilakukan pengembangan industri produk turunan dari minyak sawit ini. Produk turunan tersebut meliputi oleokimia, minyak goreng, margarin, dan biodiesel. Namun untuk menentukan produk mana yang lebih potensial untuk dikembangkan maka perlu dirancang suatu sistem penunjang keputusan yang dapat membantu dalam mengambil keputusan.

\section{Tujuan Penelitian}

Tujuan dari penelitian adalah merancang suatu sistem pendukung keputusan yang dapat memberi masukan yang berarti bagi pengembang industri produk turunan minyak sawit, dalam menentukan produk turunan yang potensial untuk dikembangkan.

\section{Ruang Lingkup Penelitian}

Ruang lingkup kajian ini dibatasi pada pengembangan industri pengolahan produk turunan $\mathrm{CPO}$ sebagai agroindustri yang berbasis sumber daya lokal. Aspek yang dibahas meliputi pemilihan alternatif produk yang akan dikembangkan berdasarkan potensi pasar, kondisi bahan baku, teknologi proses, nilai tambah produk, dan daya serap tenaga kerja.

\section{TINJAUAN PUSTAKA}

\section{Pengolahan Kelapa Sawit}

Perkebunan kelapa sawit saat ini telah berkembang tidak hanya yang diusahakan oleh perusahaan Negara, tetapi juga perkebunan rakyat dan swasta. Pada tahun 2003, luas areal perkebunan rakyat mencapai 1.827 ribu ha, perkebunan negara seluas 645 ribu ha, dan perkebunan besar swasta seluas 2.765 ribu ha. Ditinjau dari bentuk pengusahaannya, perkebunan rakyat (PR) memberi andil produksi CPO sebesar 3.645 ribu ton, perkebunan besar negara (PBN) sebesar 1.543 ribu ton, dan perkebunan besar swasta (PBS) sebesar 4.627 ribu ton.

Produksi CPO juga menyebar dengan perbandingan $85,55 \%$ Sumatera, $11,45 \%$ Kalimantan, 2\%, Sulawesi, dan $1 \%$ wilayah lainnya. Produksi tersebut dicapai pada tingkat produktivitas perkebunan rakyat sekitar 2,73 ton $\mathrm{CPO} /$ ha, perkebunan negara 3,14 ton $\mathrm{CPO} / \mathrm{ha}$, dan perkebunan swasta 2,58 ton CPO/ha (Balitbang Pertanian, 2007).

Dalam hal industri pengolahan, industri pengolahan CPO telah berkembang dengan pesat. Saat ini jumlah unit pengolahan di seluruh Indonesia mencapai 320 unit dengan kapasitas olah 13.520 ton TBS per jam. Sedangkan industri pengolahan produk turunannya, kecuali minyak goreng, masih belum berkembang, dan kapasitas terpasang baru sekitar 11 juta ton. Industri oleokimia Indonesia sampai tahun 2000 baru memproduksi oleokimia $10,8 \%$ dari produksi dunia.

Produksi CPO Indonesia pada tahun 2007 tercatat mencapai 17 juta ton dengan luas lahan kelapa sawit 7 juta hektar. Saat itu, sebanyak 75,63\% CPO dan produk turunannya diekspor, sedangkan sisanya $24,3 \%$ atau 3,9 juta ton diolah dalam negeri (Karim, 2008).

Keterbatasan pengembangan produk hilir berdampak negatif pada perkembangan pasar dan industri hilir CPO di tanah air. Minyak kelapa sawit yang ada di berbagai Negara di Eropa telah digunakan sebagai bahan untuk 
sabun, kosmetik dan bahan kecantikan. Di Indonesia justru dimanfaatkan sebagai minyak goreng.

Rencana

pemerintah mendiversifikasi produk hilir berbasis minyak sawit mentah (CPO) dari 17 menjadi 30 jenis produk untuk bahan pangan dan non pangan, terancam gagal. Penyebabnya, investasi di sektor industri hilir CPO masih k minim. Namun upaya tersebut tidak juga menunjukkan hasil yang memuaskan. Direktur Industri Makanan Ditjen Industri Agro dan Kimia, Departemen Perindustrian mengakui saat ini pihaknya menghadapi kendala dalam meningkatkan investasi di sektor hilir CPO.

Selain itu, industri turunan CPO adalah energi biodiesel dimana bahan baku utamanya adalah minyak mentah kelapa sawit atau yang lebih dikenal dengan nama Crude Palm Oil (CPO). Biodiesel ini merupakan energi alternatif yang ramah lingkungan, selain itu sumber energinya dapat terus dikembangkan, sangat berbeda dengan minyak bumi yang jika cadangannya sudah habis tidak dapat dikembangkan kembali (Tryfino, 2006).

Pertumbuhan permintaan $\mathrm{CPO}$ tidak hanya disebabkan dengan adanya pengembangan energi alternatif tersebut, tetapi juga disebabkan kenaikan permintaan yang disebabkan oleh pertumbuhan industri hilirnya. Indonesia sebagai produsen utama bersama Malaysia seharusnya dapat memperoleh keuntungan dari keadaan tersebut, dengan berkonsentrasi membangun industri kelapa sawit dan infrastruktur pendukungnya.

Persaingan biodiesel berbahan baku minyak kelapa sawit dengan yang berbahan baku kacang kedelai atau jagung yang umunya didominasi Negara maju, akan dimenangkan oleh biodiesel yang berbahan minyak kelapa sawit, karena biaya produksinya jauh lebih murah. Disamping itu dalam kapasitas produksi, minyak kelapa sawit jauh lebih besar daripada minyak kacang kedelai ataupun jagung.

\section{Proses Hierarki Analitik}

Proses hierarki analitik (Analytical Hierarchy Process - $A H P$ ) dikembangkan oleh Dr. Thomas L. Saaty dari Wharton School of Business pada tahun 1970-an untuk mengorganisasikan informasi dan judgment dalam memilih alternatif yang paling disukai. Dengan menggunakan AHP, suatu persoalan yang akan dipecahkan dalam suatu kerangka berpikir yang terorganisir, sehingga memungkinkan dapat diekspresikan untuk mengambil keputusan yang efektif atas persoalan tersebut. Persoalan yang komplek dapat disederhanakan dan dipercepat proses pengambilan keputusannya (Marimin, 2004).

Prinsip kerja AHP adalah penyederhanaan suatu persoalan kompleks yang tidak terstruktur, strategik, dan dinamik menjadi bagianbagiannya, serta menata dalam suatu hierarki. Kemudian tingkat kepentingan setiap variabel diberi nilai numerik serta subjektif tentang arti penting variabel tersebut secara relatif dibandingkan variabel lainnya. Dari berbagai variabel tersebut kemudian ditetapkan variabel yang memiliki prioritas tinggi dan berperan untuk mempengaruhi hasil pada sistem tersebut.

AHP memungkinkan pengguna untuk memberikan nilai bobot relative dari suatu kriteria majemuk (atau alternatif majemuk terhadap suatu kriteria) secara intuitif, yaitu dengan melakukan perbandingan berpasangan 
menjadi suatu himpunan bilangan yang mempresentasikan prioritas relatif dari setiap kriteria dan alternatif. Salah satu perangkat lunak yang dapat dipergunakan untuk perhitungan dalam memecahkan persoalan dengan AHP adalah Expert Chioce.

\section{METODOLOGI PENELITIAN}

\section{Kerangka Pemikiran}

Pengembangan industri pengolahan produk turunan minyak kelapa sawit melibatkan banyak pihak yang saling terkait. Masing-masing pihak mempunyai kepentingan yang berbeda-beda. Dengan demikian koordinasi masing-masing pihak yang terlibat sangat diperlukan untuk dapat membentuk suatu sistem yang terpadu.

Untuk menentukan alternatif produk turunan minyak kelapa sawit yang potensial untuk dikembangkan dilakukan analisis dengan menggunakan aplikasi Expert Choice. Expert Choice merupakan salah satu software yang bisa digunakan untuk menyelesaikan persoalan dengan prinsip kerja AHP, sehingga bisa menghasilkan pilihan alternatif produk yang paling potensial untuk dikembangkan.

\section{Penentuan Kriteria Pemilihan}

Pemilihan kriteria berdasarkan analisis pakar dan pengorganisasian dari berbagai literatur tentang kelapa sawit, yang menyatakan bahwa dalam menentukan produk agroindustri unggulan dapat didasarkan pada 5 kriteria, yaitu; kondisi bahan baku, teknologi proses, potensi pasar, nilai tambah produk, dan penyerapan tenaga kerja.

\section{Penentuan Alternatif Pemilihan}

Alternatif pilihan dari produk turunan minyak sawit meliputi; oleokimia, minyak goreng sawit, margarin, dan biodiesel. Alternatif produk ini didasarkan pada pohon industri kelapa sawit yang menggambarkan produk turunan $\mathrm{CPO}$ yang cukup berpotensi untuk dikembangkan. Untuk alternatif produk juga dilakukan pembobotan terhadap ke4 pasang alternatif.

\section{Struktur Hierarki Penelitian}

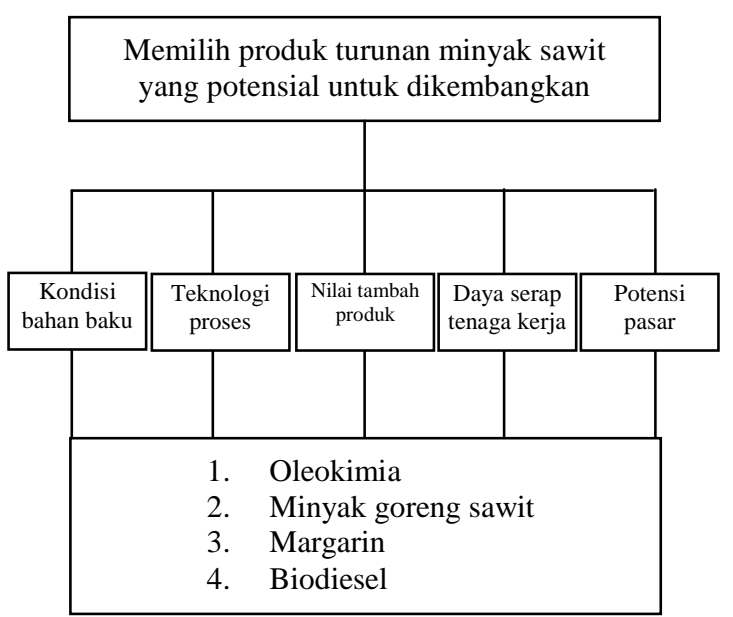

\section{Peniliaian Kriterian dan Alternatif}

Penilaian kriteria dan alternatif dilakukan berdasarkan pada studi literature dan pendapat pakar. Kriteria dan alternatif dinilai melalui perbandingan berpasangan. Menurut Saaty (1983), untuk berbagai persoalan, skala 1 sampai 9 adalah skala terbaik dalam mengekspresikan pendapat.

\section{Penentuan Prioritas}

Untuk setiap kriteria dan alternatif perlu dilakukan perbandingan berpasangan. Nilai-nilai perbandingan relatif kemudian diolah untuk menentukan peringkat relatif dari seluruh alternatif. Bobot atau prioritas 
dihitung dengan manipulasi matriks atau melalui penyelesaian persamaan matematik. Perhitungan dilakukan dengan program Expert Choice yang merupakan salah satu perangkat lunak yang dapat dipergunakan untuk pemecahanan persoalan dengan AHP.

\section{HASIL DAN PEMBAHASAN}

\section{Analisis Pemilihan Kriteria}

Pemilihan kriteria ini berdasarkan analisis pakar dan pengorganisasian dari berbagai literatur tentang kelapa sawit, yang menyatakan bahwa dalam menentukan produk agroindustri unggulan dapat didasarkan pada 5 kriteria, yaitu; kondisi bahan baku, teknologi proses yang sudah dipakai, potensi pasar, nilai tambah produk, dan penyerapan tenaga kerja.

Pembobotan kelima kriteria di atas dilakukan dengan menggunakan metode AHP (aplikasi program Expert Choice) dengan mengambil pendapat dari pakar yang digabungkan dengan literatur. Nilai eigen masing-masing kriteria tersebut dapat dilihat pada Tabel 1.

Tabel 1. Nilai Eigen pada MasingMasing Kriteria

\begin{tabular}{clc} 
Rangking & \multicolumn{1}{c}{ Kriteria } & $\begin{array}{c}\text { Nilai } \\
\text { Eigen }\end{array}$ \\
1 & Potensi Pasar & 0.515 \\
2 & $\begin{array}{l}\text { Kondisi Bahan } \\
\text { Baku }\end{array}$ & 0.255 \\
& $\begin{array}{l}\text { Teknologi } \\
\text { Proses }\end{array}$ & 0.131 \\
4 & $\begin{array}{l}\text { Penyerapan } \\
\text { Tenaga Kerja }\end{array}$ & 0.053 \\
& $\begin{array}{l}\text { Nilai Tambah } \\
\text { Produk }\end{array}$ & 0.045 \\
& &
\end{tabular}

Nilai eigen merupakan nilai yang menunjukkan tingkat kepentingan dari masing-masing kriteria. Berdasarkan nilai eigen pada Tabel 1, dapat diketahui bahwa kriteria yang paling penting adalah potensi pasar, kemudian diikuti kondisi bahan baku, teknologi proses, penyerapan tenaga kerja, dan yang kurang penting adalah nilai tambah produk.

\section{Analisis Pemilihan Alternatif}

Penentuan skor alternatif produk turunan kelapa sawit unggulan untuk masing-masing kriteria dilakukan dengan mengambil pendapat dari pakar dan pengorganisasian dari berbagai literatur tentang kelapa sawit.

\section{Potensi Pasar}

Potensi pasar merupakan kriteria pemilihan produk potensial dari turunan kelapa sawit yang penting, karena menunjukkan prospek kebutuhan akan produk turunan kelapa sawit yang potensial untuk dikembangkan, sehingga memenuhi pasar dalam negeri maupun ekspor.

Pembobotan alternatif produk berdasarkan potensi pasar dilakukan dengan menggunakan metode AHP (aplikasi program Expert Choice) dengan mengambil pendapat dari pakar yang digabungkan dengan literatur. Nilai eigen masing-masing alternatif tersebut dapat dilihat pada Tabel 2. 
Tabel 2. Nilai Eigen pada Masing-Masing Alternatif

\begin{tabular}{clc} 
Rangking & \multicolumn{1}{c}{ Alternatif } & $\begin{array}{c}\text { Nilai } \\
\text { Eigen }\end{array}$ \\
1 & Oleokimia & 0.552 \\
2 & Minyak Goreng & 0.247 \\
3 & Margarin & 0.136 \\
4 & Biodiesel & 0.065
\end{tabular}

Dari perhitungan nilai eigen tersebut, dapat diketahui alternatif produk yang paling potensial berdasarkan potensi pasar adalah oleokimia. Minyak goreng merupakan produk potensial kedua setelah oleokimia, kemudian diikuti oleh margarin, dan terakhir adalah biodiesel.

Dari keempat alternatif produk turunan kelapa sawit yang akan dikembangkan, oleokimia mempunyai peluang pasar yang lebih bagus disbanding produk lainnya. Hal ini disebabkan karena oleokimia merupakan bahan dasar pembuatan obat-obatan, kosmetik, dan berbagai jenis produk turunan lainnya. Selain itu, oleokimia mempunyai harga jual yang paling tinggi dibanding produk turunan lainnya.

\section{Kondisi Bahan Baku}

Kondisi bahan baku merupakan kriteria yang harus diperhatikan di dalam mengembangkan produk turunan minyak kelapa sawit, karena akan sangat mempengaruhi kelangsungan industri yang akan dikembangkan. Pembobotan alternatif produk berdasarkan kondisi bahan baku dilakukan dengan menggunakan metode AHP (aplikasi program Expert Choice) dengan mengambil pendapat dari pakar yang digabungkan dengan literatur. Nilai eigen masing-masing alternatif tersebut dapat dilihat pada Tabel 3.
Tabel 3. Nilai Eigen pada Masing-Masing Alternatif

\begin{tabular}{clc} 
Rangking & \multicolumn{1}{c}{ Alternatif } & $\begin{array}{c}\text { Nilai } \\
\text { Eigen }\end{array}$ \\
3 & Oleokimia & 0.150 \\
1 & Minyak Goreng & 0.472 \\
4 & Margarin & 0.104 \\
2 & Biodiesel & 0.274
\end{tabular}

Dari keempat alternatif produk turunan minyak kelapa sawit, minyak goreng sawit merupakan produk yang paling terjamin bahan bakunya. Hal ini disebabkan karena penggunaan $\mathrm{CPO}$ sebagai bahan dasar minyak goreng mencapai $71 \%$ dari produksi CPO, dan bila digabung dengan margarin sekitar $75 \%$. Sisanya sekitar $25 \%$ merupakan bahan baku untuk oleokimia. Sedangkan biodiesel merupakan produk yang memerlukan bahan baku dari minyak sawit dengan mutu terendah, yang tidak layak dikonsumsi atau dijadikan minyak goreng.

\section{Teknologi Proses}

Teknologi proses yang sudah dipakai merupakan kriteria yang perlu diperhatikan, karena mempengaruhi produk turunan minyak kelapa sawit yang akan dikembangkan. Kriteria ini diperlukan untuk melihat apakah untuk memproduksi produk tersebut sudah ada teknologi yang dipakai baik di dalam negeri maupun di luar negeri. Apabila produk yang akan dikembangkan tersebut baru pada tahap skala laboratorium berarti teknologinya belum terjamin.

Pembobotan alternatif produk berdasarkan teknologi proses dilakukan dengan menggunakan metode AHP (aplikasi program Expert Choice) dengan mengambil pendapat dari pakar 
yang digabungkan dengan literatur. Nilai eigen masing-masing alternatif tersebut dapat dilihat pada Tabel 4 .

Tabel 4. Nilai Eigen pada Masing-Masing Alternatif

\begin{tabular}{clc} 
Rangking & \multicolumn{1}{c}{ Alternatif } & $\begin{array}{r}\text { Nilai } \\
\text { Eigen }\end{array}$ \\
3 & Oleokimia & 0.095 \\
1 & Minyak Goreng & 0.632 \\
2 & Margarin & 0.198 \\
4 & Biodiesel & 0.075
\end{tabular}

Dari keempat produk turunan minyak kelapa sawit di atas, minyak goreng sawit mempunyai teknologi yang sudah cukup baik, hal ini ditandai dengan banyaknya industri yang mengolah minyak goreng sawit. Selanjutnya, margarin menempati posisi kedua yang diikuti oleh oleokimia dan biodiesel.

\section{Penyerapan Tenaga Kerja}

Penyerapan tenaga kerja merupakan kriteria yang digunakan untuk melihat apakah produk turunan minyak kelapa sawit yang akan dikembangkan memerlukan tenaga yang besar atau hanya sedikit. Apabila banyak tenaga kerja yang akan dipakai, maka dalam penilaiannya akan mempunyai nilai yang besar.

Pembobotan alternatif produk berdasarkan penyerapan tenaga kerja dilakukan dengan menggunakan metode AHP (aplikasi program Expert Choice) dengan mengambil pendapat dari pakar yang digabungkan dengan literatur. Nilai eigen masing-masing alternatif tersebut dapat dilihat pada Tabel 5.
Tabel 5. Nilai Eigen pada Masing-Masing Alternatif

\begin{tabular}{clc} 
Rangking & \multicolumn{1}{c}{ Alternatif } & $\begin{array}{c}\text { Nilai } \\
\text { Eigen }\end{array}$ \\
1 & Oleokimia & 0.383 \\
2 & Minyak Goreng & 0.273 \\
3 & Margarin & 0.219 \\
4 & Biodiesel & 0.125
\end{tabular}

Dari keempat produk turunan minyak kelapa sawit yang akan dikembangkan di atas, oleokimia merupakan produk yang paling banyak menyerap tenaga kerja. Hal ini disebabkan karena oleokimia merupakan produk yang bisa dikembangkan lagi menjadi produk obat-obatan, kosmetik, dan produk turunan lainnya. Sedangkan minyak goreng, margarin, dan biodiesel mempunyai nilai penyerapan tenaga kerja yang relatif sama.

\section{Nilai Tambah Produk}

Nilai tambah produk merupakan kriteria yang cukup penting diperhatikan, karena menunjukkan besarnya keuntungan yang diperoleh apabila produk unggulan tersebut dikembangkan. Pembobotan alternatif produk berdasarkan nilai tambah produk dilakukan dengan menggunakan metode AHP (aplikasi program Expert Choice) dengan mengambil pendapat dari pakar yang digabungkan dengan literatur.

Dari perbandingan berpasangan tersebut, dapat dihitung nilai eigen dari masing-masing kriteria, sehingga dapat ditentukan rangking dari masing-masing alternatif. Nilai eigen tersebut dapat dilihat pada Tabel 6 . 
Tabel 6. Nilai Eigen pada Masing-Masing Alternatif

\begin{tabular}{clc} 
Rangking & \multicolumn{1}{c}{ Alternatif } & $\begin{array}{c}\text { Nilai } \\
\text { Eigen }\end{array}$ \\
1 & Oleokimia & 0.456 \\
2 & Minyak Goreng & 0.248 \\
3 & Margarin & 0.230 \\
4 & Biodiesel & 0.066
\end{tabular}

Dari keempat produk turunan minyak kelapa sawit di atas, oleokimia mempunyai nilai tambah produk yang lebih baik dibandingkan produk lainnya. Hal ini disebabkan karena oleokimia merupakan produk yang sangat dibutuhkan sebagai bahan baku obatobatan, kosmetik, dan produk lainnya yang harganya relatif mahal.

Minyak goreng dan margarin mempunyai nilai tambah yang relatif stabil. Hal ini disebabkan karena minyak goreng dan margarin merupakan bahan pangan yang cukup dibutuhkan dalam masyarakat. Sedangkan nilai tambah produk biodiesel sangat kecil, karena biodiesel merupakan produk yang belum tersosialisasikan dengan baik, sehingga harganya pun belum bisa dipastikan.

Hasil analisis pemilihan produk turunan minyak kelapa sawit diperoleh dengan cara mengalikan matriks nilai eigen dari alternatif dengan matriks bobot kriteria. Namun dengan menggunakan aplikasi Expert Choice, perhitungan tidak perlu dilakukan secara manual karena hasilnya akan diperoleh secara otomatis.

Dengan memperhatikan uraianuraian di atas, maka hasil analisis pemilihan produk turunan minyak kelapa sawit yang potensial untuk dikembangkan serta perhitungannya dapat dilihat pada Tabel 7.

Tabel 7. Matriks Keputusan Penentuan Produk Unggulan Berbasis CPO

\section{Kriteria}

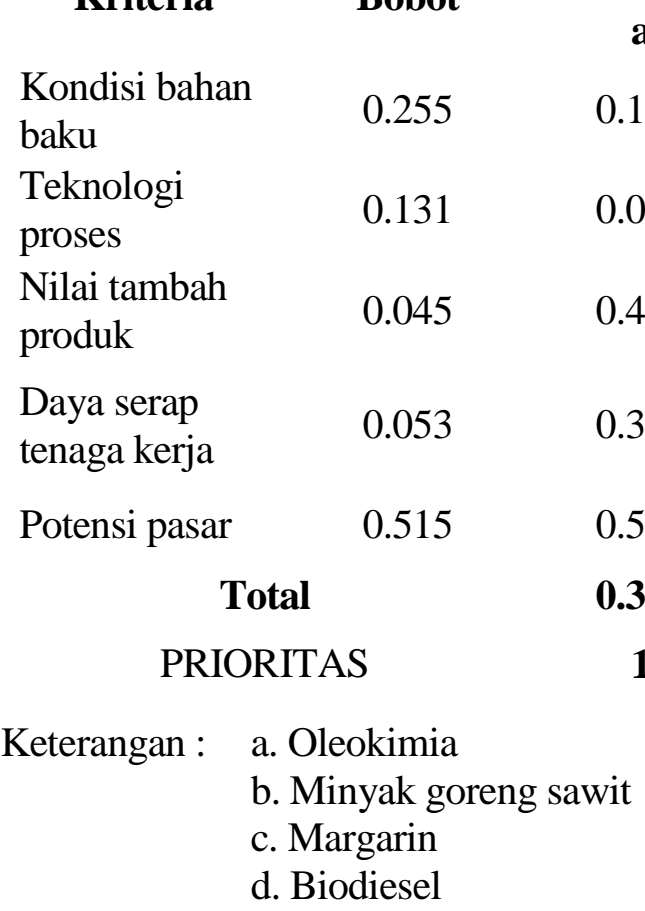

\section{Alternatif Produk}

a

b

c

d

$\begin{array}{lll}0.472 & 0.104 & 0.274\end{array}$

$\begin{array}{lll}0.632 & 0.198 & 0.075\end{array}$

$\begin{array}{lll}0.248 & 0.230 & 0.066\end{array}$

$\begin{array}{lll}0.272 & 0.219 & 0.125\end{array}$

$\begin{array}{lll}0.247 & 0.136 & 0.065\end{array}$

$\begin{array}{lll}0.354 & 0.144 & 0.129\end{array}$

12

3 
Berdasarkan hasil perhitungan tersebut maka didapatkan urutan unggulan produk turunan minyak kelapa sawit yang potensial untuk dikembangkan. Prioritas pertama ditempati oleh oleokimia yang diikuti oleh minyak goreng sawit, margarin, dan prioritas terakhir adalah biodiesel.

Untuk lebih mengembangkan agroindustri berbasis CPO di Indonesia, maka perlu diupayakan suatu agroindustri yang terpadu. Hal ini untuk mengatasi kesulitan berbagai faktor yang mungkin terjadi, baik kebutuhan bahan baku, teknologi yang digunakan, pemasaran, dan sebagainya. Selain itu berbagai pihak terkait juga harus mendukung dalam pengembangan produk turunan minyak kelapa sawit ini.

\section{KESIMPULAN DAN SARAN}

\section{Kesimpulan}

Penelitian ini menghasilkan beberapa kesimpulan sebagai berikut:

1. Basis model yang dikembangkan dalam sistem penunjang keputusan ini adalah model yang dapat digunakan untuk membantu pengambilan keputusan dalam perencanaan pengembangan produk turunan minyak kelapa sawit yang potensial untuk dikembangkan. Hasil penilaian kriteria berturut-turut dari nilai yang terbesar adalah potensi pasar, kondisi bahan baku, teknologi proses, penyerapan tenaga kerja, dan nilai tambah produk.

2. Berdasarkan potensi pasar, prioritas alternatif produk turunan dari nilai yang terbesar adalah oleokimia, minyak goreng sawit, margarin, dan biodiesel.

3. Berdasarkan kondisi bahan baku, prioritas alternatif produk turunan dari nilai yang terbesar adalah minyak goreng sawit, biodiesel, oleokimia, dan margarin.

4. Berdasarkan teknologi proses, prioritas alternatif produk turunan dari nilai yang terbesar adalah minyak goreng sawit, margarin, oleokimia, dan biodiesel.

5. Berdasarkan penyerapan tenaga kerja, prioritas alternatif produk turunan dari nilai yang terbesar adalah oleokimia, minyak goreng sawit, margarin, dan biodiesel.

6. Berdasarkan nilai tambah produk, prioritas alternatif produk turunan dari nilai yang terbesar adalah oleokimia, minyak goreng sawit, margarin, dan biodiesel.

7. Hasil verifikasi model dan analisis menunjukkan bahwa prioritas produk turunan minyak kelapa sawit yang potensial untuk dikembangkan berturut-turut adalah oleokimia, minyak goreng sawit, margarin, dan biodiesel.

\section{Saran}

Untuk mendukung pengembangan agroindustri produk turunan minyak kelapa sawit, basis model pada sistem penunjang keputusan ini perlu dikembangkan lebih lanjut. Basis model tersebut adalah basis model pemilihan kawasan, basis model kelayakan agroindustri, dan basis model strategi pengembangan agroindustri. 


\section{DAFTAR PUSTAKA}

Adlin U.L., 1992. Kelapa Sawit di Indonesia. Pusat Penelitian Perkebunan Marihat-Indonesia.

Badan Penelitian dan Pengembangan Pertanian. 2007. Prospek dan Arah Pengembangan Agribisnis: Kelapa Sawit. $\quad$ www.deptan.go.id $\quad(10$ Februari 2012).

Karim, Yusuf. 2008. Garap Sektor Hilir CPO. www.inilah.com (10 Februari 2012).

Kusnandar dan Marimin. 2004. Pengembangan Produk Agroindustri Jamu dan Analisis Struktur Kelembagaannya. TIP IPB. Bogor.

Kristanto, Heru. 1999. Sistem Pengembangan Agroindustri Komoditas Unggulan pada Kawasan Andalan: Studi Kasus di
Kabupaten Ciamis, Jawa Barat. Program Pascasarjana IPB. Bogor.

Marimin. 2004. Teknik dan Aplikasi Pengambilan Keputusan Kriteria Majemuk. Grasindo. Jakarta.

Risza, Suyatno. 1994. Upaya Peningkatan Produktivitas Kelapa Sawit. Penerbit Kanisius. Yogyakarta.

Tim Standarisasi Pengolahan Kelapa sawit. 1997. Pengolahan Kelapa Sawit. Direktorat Jenderal Perkebunan. Jakarta.

Tryfino. 2006. Potensi dan Prospek Industri Kelapa Sawit. Economic review. www.bni.co.id (10 Februari 2012).

Udrekh. 2007. Melirik Perkembangan Industri Kelapa Sawit Indonesia. www.beritaiptek.com (10 Februari 2012) 